\title{
Analysen af nye sociale bevægelser - teorier og begreber.*
}

\author{
Roland Roth
}

Videnskab er den erkendelse, der opstår i de af folket selv frembragte sociale bevægelser. (Marx)

Nye sociale bevægelser - et samlebegreb for de protestgrupper og politiske strømninger, der er dukket op fra og med studenterbevægelsen sidst i 60'erne ( $\varnothing$ kologibevægelsen, den nye kvindebevægelse, alternativgrupper, borgerinitiativer, regionale bevægelser m.m.) - begynder nu lidt efter lidt at vinde indpas i de socialvidenskabelige og politiske diskussioner. Begrebets historie peger - udover de mangfoldige fors $\emptyset \mathrm{g}$ på forklaringer og vurderinger (Brandt 1982 giver en god oversigt) - på, at de sociale og politiske forhold, som får denne etiket påklæbet, ikke længere kan betragtes som forbigående og perifere og dermed overses. I de sidste ti år har protestkulturen i virkeligheden udvidet sig og påvirker de etablerede partiers og organisationers politiske kultur på trods af alle profetier om, at aktivisterne bare var borgere, der var vildledt af velstand og reformløfter og som snart ville besinde sig i lyset af den næste økonomiske krise. De nye sociale bevægelser er i al deres amøbeagtige foranderlighed yderst sejlivede.

Ud fra den yderst omfattende mængde forklaringsfors $\emptyset \mathrm{g}$, som findes idag, vil jeg her diskutere nogle, som fremhæver de nye sociale bevægelser som et nøglefænomen. Heri sammenkædes politiske og samfundsteoretiske motiver. For det første skal de nye sociale bevægelser analyseres ud fra deres mulige samfundsforandrende potentiale og for det andet give et indblik i de opbrudssituationer, hvoraf de er opstået. Heri ligger også et perspektiv »hinsides krisen« som de kunne bebude.

Optimismen i denne socialvidenskabelige interesse bygger på håbet om igen at kunne knytte det »sønderrevne bånd « mellem en mere og mere akademiserende videnskab og sociale bevægelser, og dermed åbne for meningsfyldte politiske horisonter for den videnskabelige praksis. At der

* Oversat fra Politische Vierteljahresschrift 1983, heft 3 af Jens Henning Rasmussen og Finn Hansson 
hermed rejser sig en række politiske og teoretiske problemer ligger lige for, navnlig da bevægelsernes »empiri« spærrer for videnskabelig gennemtrængning. I denne situation forekommer det mig at være meningsfyldt at klargøre de politiske og teoretiske implikationer, som dukker op, når vi vil give de nye sociale bevægelser en nøgleposition i vores begrebsdannelser. I det følgende kommer først en indkredsning af aktuelle politiske positioner (I) og i forlængelser heraf fire samfundsvidenskabelige forklaringsfors $\emptyset \mathrm{g}$ (II).

\section{De politiske vurderingers underskov.}

Begrebet »nye sociale bevægelser« signalerer allerede, at det her drejer sig om mere end en vilkårlig opregning af aktuelt kendte protestbevægelser, en slags dagsaktuel politisk tværsum. Indtil det 20. århundrede var »sociale bevægelser« et synonym for de forskellige strømninger og projekter i arbejderbevægelsen. Spørgsmålet er nu, om de nye sociale bevægelser er en epokegørende kraft, der efterfølger eller kan efterfølge arbejderbevægelsen, eller om sådanne forhåbninger er helt urimelige og fejlagtige? Her følger nogle stikord der kan tydeliggøre dette spørgsmål:

\section{Marxismens krise, tvivlen på »arbejderbevægelsens centrale rolle«.}

Den faldende betydning eller tilbagegang, som traditionelle socialistiske og kommunistiske partier i Vesteuropa har oplevet siden midten af 70 'erne, samt de fejlslagne »venstreradikale« fornyelsesfors $\emptyset \mathrm{g}$ i tilknytning til den »proletariske bølge« fra den antiautoritære protestbevægelse i 60'erne, har tilsammen forstærket tvivlen på den historiske mission og forandringskraft i den fagforeningsmæssige og politiske organisation i industriarbejderklassen - selvom dette ikke sker for første gang i den vestlige marxismes historie. »Farvel til proletariatet « (Gorz 1980), farvel til arbejderbevægelsens revolutionære mytologi blev (endnu engang) skreget ud. Ordet »bevægelse« hænger nu kun fast på dens forstenede institutionelle praktiker som et knaphulsmærke fra gamle dage; virkelige bevægelser findes snarere i udkanten af og i voksende omfang udenfor de organiserede fabriksarbejdere. »Marxismens krise« viste sig i Italien og Frankrig først og fremmest som en krise for de kommunistiske partier, men blev også diskuteret på den vesttyske venstrefløj (Evers 1980, Prokla 36/1979). En grundlæggende skepsis overfor radikale politiske forandringsperspektiver blev fremført med argumenter som: fastholdelse i en konsum- og vækstmodel, det levende arbejdes underordning og tab af kompetence til maskineri og management. Den centrale konflikt i industrisamfundet mellem lønarbejde og kapital skulle være be- 
røvet sin sprængkraft og den tidligere motor i akkumulationsprocessen sin negatoriske kraft. En systemforandrende bevægelse eller en central samfundsmæssig konflikt syntes dermed ikke at have nogen oprindelse. Udenforstående grupper, marginaliserede og protestgrupper blev hurtigt sammenfattet - mere af forlegenhed end af overbevisning - og bragt $\mathrm{i}$ spil som mulige efterfølgere (f.eks. »ikke-klassen af ikkearbejdere« hos Gorz 1980).

\section{En ny bevægelses fødsel - bærere og forformer for et efterkapitalistisk samfund.}

Ansigt til ansigt med fraværet af bevægelse i de regulerede industrielle forhold og ritualiserede overenskomstforhandlinger, minder den brogede mængde af sociale bevægelser med deres kulturelle modbilleder og sociale eksperimenter om arbejderbevægelsens konstitutionsproces i det 18. og 19. århundrede, som netop tog form af lange lære- og kampcyklus'er ud fra en mængde politiske og sociale strømninger og kollektive eksperimenter (eksemplarisk Thompson 1963, Vester 1970 og 1983). Peger opbrudsstemningen, heterogeniteten og mangfoldigheden i den nye sociale bevægelse ikke på, at de bærer muligheden og potentialet i sig til at blive et omfattende modsvar til kapitalistisk samfundsmæssiggørelse? Den fantasifulde og mangesidige begyndelse har idag ikke mere baggrund i de førkapitalistiske moderfaringer fra »moraløkonomien« (Thompson 1980), men er efterkapitalistiske eksperimenter, der er muliggjort af sidestillingen mellem samfundsmæssig rigdom og den herskende akkumulationsmodels krise (massearbejdsløshed med et højt reproduktionsniveau, udbredelse af informelle sektorer, osv.). Der søges her efter samfundsmæssige alternativer, mens de »proletariske traditionsforeninger « står udenfor, hjælpeløse overfor denne praktiske kritik af deres deformation.

Ud fra dette synspunkt er det brogede billede som de nye bevægelser udgør, en indikator på én ny bevægelses svære konstitutionsproces (Evers/Szansky 1981). Den videre programmatiske og organisatoriske udvikling, politiske aktionsformer og forbund, er i dette perspektiv åbne, da de også er resultatet af selvkonstitutionen af en bevægelse, der er samfundsmæssig mulig, men på ingen måde nødvendig. Læreprocesser i sammenhæng med et efterkapitalistisk perspektiv eller integration og forlis er alternative muligheder, som ikke alene lader sig bestemme ud fra systemkrisens dybde og de herskendes integrations- og repressionsstrategier. De materielle betingelser for et efterkapitalistisk samfund er i lige så høj grad til stede som de subjektive og kollektive potentialer, der presser i denne retning. Fremtiden er genstand for opgør og kamp. 
Nye sociale bevægelser som ungdommens kilde for arbejderbevægelsen, forbundsperspektivet.

I diskussionerne om efterfølgere til den centrale rolle i samfundsmæssige forandringsprocesser blev der hurtigt ytret tvivl. Har vi ikke stadig at gøre med et kapitalistisk samfund, er bevidste samfundsmæssige forandringer uden aktiv deltagelse af den lønafhængige befolkning ikke utænkelig? Arbejderbevægelsens monumentale fremtoning kan man ikke sådan uden videre komme uden om. Er det ikke sådan, at de temaer, som kommer til udtryk i de nye sociale bevægelser - forbrugs- og herredømmekritikken, spørgsmålet om arbejdets mening og produkternes nytte, kritikken af de umyndigg ørende medicinske apparater og af den bureaukratiske socialforsorg - alle er spørgsmål, som fuldstændigt kan integreres i diskussionerne $\mathrm{i}$ bestemte strømninger $\mathrm{i}$ arbejderbevægelsen, navnlig når de dér engang er blevet rejst (mht. en anarkistisk kritik af sociale og politiske organisationsformer, se Narr 1980)? Gælder det ikke i første omgang om at udvide den historisk udvandede og institutionelt afgrænsede strøm af interessevaretagelser og lade nyt vand, som i arbejderbevægelsens historie er blevet fyldt op og dæmmet ind, strømme frit?

Som eksempel på en sådan mulighed fremhæves oftest venstrefagforeningen CFDT eller ombytningsmodellen fra Lucas Aerospace (Rolant i Gorz 1980, diskussionen i Prokla 39/1980 og Löw-Beer 1981). Ligger fremtiden for forholdet mellem de nye bevægelser og arbejderbevægelsen ikke i en gensidig kritik og supplering på trods af placeringen som modstandere i aktuelle konflikter (f.eks. i atomkraftdiskussionen og økologiske konflikter)? Det ligger lige for at komme med forbehold overfor denne harmoniske model. Socialdemokratiet og fagforeningerne hører til de bærende kræfter i en vækstorienteret $\varnothing$ konomi, til den »produktivitetsorienterede kerne «, hvis destruktive kræfter de nye sociale bevægelser er stødt imod i talrige projekter og demonstrationer (Model-Deutschland diskussionen er en særlig konkretisering af denne problemstilling i BRD, se Leviathan 1/1979, Prokla 40 og 41/1980)?

\section{Mange bevægelser, men ingen bevægelse.}

Inddragelsen af arbejderbevægelsen i diskussionen af de nye sociale bevægelser fremtvinger radikale samfundsteoretiske konsekvenser. Hvis disse tilbagevises og hvis den kapitalistiske produktionsmådes og samfundsmæssiggørelses kvalitativt uforandrede kontinuitet fremhæves, så følger det af den traditionelle arbejderbevægelses omfattende samfundsmæssige integration, at dens negatoriske styrke var bundet til overgangsfasen og den tidlige periode $\mathrm{i}$ den kapitalistiske produktionsmåde, til pauperiserings- og proletariseringserfaringerne $\mathrm{i}$ forbindelse med indu- 
strialiseringen, og relateret til solidariske værdimønstre af førkapitalistisk oprindelse (landsbyfællesskab og håndværkerlaugstraditioner). I forbindelse med kapitalismens gennembrud var det kun samfundsmæssige randgrupper, der forsøgte at dæmme op for eller trække sig tilbage fra akkumulationsdynamikkens moderniserende og permanent forandrende virkninger (fra konservativ bykritik og havebyer ved århundredeskiftet over vandrebevægelser og bohemer til dagens hippier og modkultur).

Dette »ubehag ved det moderne « (Berger m.fl. 1975) har ledsaget den samfundsmæssige udvikling med en oftest konservativ melodi, uden at kunne angive en grundtone eller fremvise et selvstændigt samfundsmæssigt levedygtigt tema. Det negatoriske centrum ser ud til at være uden oprindelse - en central samfundsmæssig konflikt kan ikke længere pilles ud. Det er netop de nye sociale bevægelsers diffushed, deres stakåndethed og manglende fællesnævner, der i denne sammenhæng taler for denne tese, som iøvrigt hører til grundudstyret i konservative afværgemekanismer (helt ind $\mathrm{i}$ arbejderbevægelsen).

I diskussionen om de nye sociale bevægelser findes en overflod af historiserende fors $\emptyset \mathrm{g}$ på at eftervise en mere eller mindre centralt placeret tilstedeværelse af konservativ eller endog fascistisk kapitalismekritik. Den konservative neoromantiske »revolution « bliver alt efter tilhørsforhold enten hilst velkommen eller bekæmpet (Mayer-Tasch 1980, Pohrt 1980, Peters 1980, Guggenberger 1980). Det er ubestrideligt, at gamle ideologiske tanke- og kritikmønstre genoplives og har en specifik plads i de aktuelle bevægelser (Kraushaar 1978, Schimank 1981). Den ideologikritiske eller idéhistoriske metode fortrænger dog alt for ofte de forandrede historiske sammenhænge.

Dette korte strejftog gennem den politiske debat om de nye sociale bevægelser gør det klart, at talen om deres epokegørende rolle eller opskrivningen af dem til nøglefænomen i sig selv er yderst flertydigt. Spektret rækker fra forhåbninger om en revolutionær samfundsforandrende kraft, som kan gribe arbejderbevægelsens uindløste program og virkeliggøre det med nye hovedlinier, over forestillinger om en forbindelse mellem den »gamle« arbejderbevægelse og de nye strømninger som kan låne de gamle tanker ny bevægelighed (Glotz 1982); og videre den mere skeptiske diagnose, at den brogede revolte forlængst har beseglet afslutningen på revolutionære forhåbninger på det givne samfundsmæssiggørelsesniveau (således Ellul 1974), men med et håb om en omlægning til en anden forestilling om forandring (grassrooting the system), som forudsætter sammenfletning af de talløse initiativer, til forestillingen om en »konservativ revolution«, der vil bevare, redde og dæmme op for følgerne af den fremadskridende samfundsmæssiggørelse, bureaukratisering og naturødelæggelse. 


\section{Samfundsteoretiske begreber}

De, der forestiller sig, at samfundsvidenskabelige anstrengelser har resulteret i en afklaring af den politiske debat, vil hurtigt blive skuffede. Det teoretiske terræn er på ingen måde fast. Eftersom de stort anlagte samfundsvidenskabelige projekter let resulterer i en følelse af afmagt, så er diskussionen af nye sociale bevægelser domineret af forklaringsfors $\varnothing \mathrm{g}$ med begrænset rækkevidde, der forsøger at opbygge et fast, empirisk gyldigt grundlag under de luftige politiske kontroverser. Resultaterne maner dog til skepsis, hvad to eksempler skal vise.

Der er voksende tilslutning til dem, der beskriver de nye sociale bevægelser som bærere af nye værdier, holdninger og af en ny livsmåde. Det faste dogme hos politiske dialogstrateger og litteraturproducenter er, at krisen i de industrielle værdimønstre er årsagen, og en post-materiel orientering er budskabet fra de nye aktører (et godt eksempel herpå er delrapporten fra 1982 fra spørgeskemaundersøgelseskommissionen »Ungdomsprotest i den demokratiske stat«). »Bevidsthedsændring «, »eksemplarisk praksis « og »oplevet utopi« er stikord fra den ideologiserede diskussion i og omkring de nye strømninger, som dækker over og politisk skærper den samfundsmæssige konflikt ved hjælp af snak om kulturelle værdiholdninger.

Hvad der sker samfundsmæssigt med de utvivlsomt tilstedeværende alternative kulturelle motiver og mønstre, hvad de betyder i praksis og for bevægelsernes perspektiver, hvilke chancer og hvilke funktioner deres gennemsætning har i sammenhæng med de givne $\emptyset$ konomiske og politiske strukturer og kriseprocesser - dét lader sig ikke afgøre videre på værdiplanet. Således kan det heller ikke undre nogen særligt, når en af protagonisterne for værdiskifteopfattelsen koncentrerer sin analyse på identificeringen af en »ny elite«, som er opstået af protestbevægelserne i 60'erne, og dermed kun indrømmer protestindholdet i 70'erne ( $\varnothing$ kologiske og antinukleare temaer) en status af ideologiske rekvisitter (Inglehart 1981). Ud over denne realistisk antagende opfattelse af en eliteudveksling, stimulerer værdiskifteopfattelsen imidlertid også »idealistiske « forventninger, som f.eks. tiltroen til en langsigtet bevidsthedsændring, der til sidst kulminerer i en epokal ombrydning (med frelsetoner hos Bahro 1980), eller håbet på protestens list, som mod dens radikale fremtoning vil ende som hjælpende korrektur for den kapitalistiske samfundsmæssiggørelse (Mast 1980, Schimank 1981). Det problematiske er ikke i første linie troværdigheden i sådanne formodninger, men derimod deres begrundelsesniveau.

Dette gælder også for de fortolkningsretninger, som fikserer den samfundsmæssige værdiændring på et mikroniveau, dvs. koncentre- 
rer sig om det i de nye sociale bevægelser indeholdte eller udfoldede potentiale af nyformede mellemmenneskelige relationer, et forandret forhold til naturen, kropsligheden, den produktive virksomhed, fritiden eller kønsrollerne. Bevægelsernes tiltrækningskraft, dynamik og resonans formes ganske sikkert ikke ubetydeligt af disse $\emptyset$ nskede eller praktiserede sociale nyorienteringer og de heraf frisatte energier - såvel som usikkerheder og blokeringer. De nydefinerer delvist - i det mindste indenfor bevægelsesaktiviteterne - feltet for det »sociale « og ryster vanemæssige samfundsmæssige af- og udgrænsninger. Opsplitningen mellem det intime, det intime, det private og det offentlige, mellem politik og samfund, bliver svækket. Således avancerer bl.a. ægteskabelige magtforhold, racistiske og kønsspecifikke diskrimineringer, den programmerede isolation i den byplanmæssige funktionalisme samt dennes følger til kritikobjekter for et oprejst »borgersamfund (Gorz 1980a). Forandringen af sociale relationer - som herredømmets mikrologi - står i centrum for talrige selvhjælpsprojekter og kollektive udbrudsfors $\emptyset \mathrm{g}$ af subkulturer og ghettoer, som f.eks. i bøssebevægelsen eller de »grå pantere «. Relevansen af disse revolter og frigørelsesfors $\varnothing g$ må ikke undervurderes, og de er tæt knyttet til de nye sociale bevægelser (jvf. Kitsuse 1980, Kriminalsoziologische Bibliografie 32-33/1981). Men at koncentrere sig om dette niveau af analysen vil imidlertid føre til forkortelser. Hverken smeltehyttelandsbyen i Flörsheimer Wald eller kommuneerfaringerne fra »Republik Freies Wendland « lader sig stilisere til centrum for den $\varnothing$ kologiske protest, heller ikke selv om de for en tid stod i de politiske begivenheders midtpunkt.

Disse forkortelser og udblændinger i værdiændringsdiskussionen underst $\varnothing t t e r$ kravet om en samfundsteoretisk orienteret diskussion af de nye sociale bevægelser, også selv om der fra dette miljø er meget lidt efterspørgsel at spore. I modsætningen til protestbevægelsernes studenterprægede begyndelse, hvor den teoretiske refleksion var et centralt medium for selvforståelsen, domineres de forskellige bevægelsessegmenter nu af indsnævrede diskurser, som bekymrer sig meget lidt om deres almengørelsesmuligheder. Samfundsteori har dér i lang tid ikke været anset for nøgle til samfundsforandrende praksis. Dermed står også det teoretiske krav selv til diskussion: revolutionær teori eller videnskabelige bagtrop, magtdiskurs eller anst $\varnothing$ dil aktørernes selvafklaring? Teoriens praksis er i sammenhæng med de nye protestbevægelser blevet særlig prekær.

I enkelttilfælde har denne usikkerhed også ført til nye kooperationsformer mellem videnskab og bevægelser, eksempelvis folkehøjskolen Wyhler Wald, skovuniversitetet i Walldorf ved Frankfurt eller det vok- 
sende antal videnskabsbutikker. Ansatser, som er mindre rettet mod den praktiske understøttelse og mere mod sociologisk opklaring af aktørerne, er i systematisk reflekteret form indtil nu kun fors $\emptyset \mathrm{gt}$ af en forskergruppe omkring Alain Touraine (for selve positionen se Touraine 1978 og som anvendelseseksempel Touraine m.fl. 1982).

Om det i disse enkelte fors $\emptyset \mathrm{g}$ er lykkedes at nå til en mere vedvarende tilnærmelse mellem teori og bevægelse må endnu undersøges. Dilemmaet som helhed har de imidlertid næppe formindsket. Således forbliver også de tolknings- og forskningsansatser, som skitseres i det efterfølgende, i en ejendommelig svævetilstand over aktivisternes hoveder og har selv kun vundet begrænset indpas i diskussionerne i basis.

\section{Herbert Marcuse}

I de nye sociale bevægelsers selvrefleksion er allerførst den senkapitalisme-tese, som blev udviklet i omegnen af den Kritiske Teori, blevet virksom - frem for alt i den version, som Herbert Marcuse selv har fremført i bevægelsernes diskussioner (jvf. biografien af Katz 1982 og fortolkningerne hos Claussen 1981). Den tager sit udgangspunkt i efterkrigserfaringen om en manglende samfundsmæssig opposition i de kapitalistiske metropoler og ser årsagerne hertil i den relativt sikrede materielle behovstilfredsstillelse og i massekulturelle behovs- og bevidsthedsmanipulationer. I den dybt integrerede og beherskede klasses »lykkelige bevidsthed « lod der sig ikke udpege nogen spor af en subjektiv nødvendighed for radikal omvæltning, selvom den objektive nødvendighed af en sådan fremstod stadig mere påtrængende (Marcuse 1967). Enheden af fremskridt og undertrykkelse, af velfærds- og krigsfærdsstat giver sig af den grundlæggende irrationalitet i den samfundsmæssige produktion, som både forøger det bestående samfunds materielle rigdom - en nødvendig forudsætning for radikal omvæltning - og udvider mulighederne for politisk og social kontrol og lammelse af de kræfter, der tilstræber samfundsforandring. »Alle materielle og intellektuelle kræfter, som kunne indsættes for realiseringen af et frit samfund, er tilstede.«(Marcuse 1980: 12). Men oppositionen koncentreres nødvendigvis i det bestående samfunds randgrupper, ghettobefolkningen og de underpriviligerede samt de priviligerede lag, som kan sætte sig imod den manipulerende samfundsmæssige styring, eksempelvis som det kom til udtryk i studenterbevægelserne. De antiautoritære protestbevægelser er alene katalysatorer eller »katalysegrupper« for den samfundsmæssige omvæltning og ikke et nyt »revolutionært subjekt «, som træder i stedet for den dybt integrerede arbejderbevægelse (Marcuse 1978, Claussen 1981). Deres betydning ligger i deres negatoriske potenser, i den kraft 
af »rebellerende subjektivitet «, som forbereder eller udvikler en desintegrativ, krisemæssig samfundsudvikling.

Ud af katalysegrupperne kan der opstå en »ny populisme«, som praktisk kritiserer den leninistiske model for den proletariske revolution gennem en "partikulær klasse« og i stedet begriber individualiteten (og ikke det »objektive klassetilhørsforhold «) som basis for frigørelsen (således Marcuse 1978 i tilknytning til Bahros »Alternativet«). Teori retter sig i denne opfattelse mod vækkelsen og forstærkelsen af det intellektuelle grundlag for de negatoriske kræfter, idet den henviser til regressive fortolkninger (naturmystik, romantisk teknikkritik, »ny inderlighed «, »politik i første person«) og integrationstendenser i bevægelserne og konfronterer disse med konsekvent overprægnante analyser af samfundsmæssige udviklingstendenser. Målet er ikke en samlet teori, som fors $\varnothing$ ger sig med objektivistiske revolutionskalkyler, men derimod kritisk orienteringshjælp mod revolternes fejltagelser. Anknytningen til protestpotentiale tabes af de yngre forfattere, som ganske vist forholder sig til analysen af den »negative samfundsmæssigg ørelse «, men imidlertid opfatter denne som overmægtig og »reelt subsumerende « (eksemplarisk hos Breuer 1977, 1978). Marcuse blev således erklæret for en »død hund «: »Netop hans yderste vilje til revolution, som gennemtrænger hele hans tænkning, lader endelig denne fremtræde som det, den er blevet til under den fuldendte kapitalismes betingelser: en kimære. Idet Marcuse i en åndeløs anstrengelse, hvor man allerede aner hele forgævesheden i hans forehavende, endnu engang gennemspiller alle revolutionsteoriens muligheder - fra utopisk socialisme over elendighedsteori til surrogatformerne af en marxistisk forklædt reprise for den borgerlige opklaring og den tyndslidte apoteose for 'umiddelbar behovstilfredsstillelse' - lader han dens objektive umulighed træde frem« (Breuer 1977, s. 241f). Denne negative anmeldelse, som er udfærdiget ud fra den høje forventning om en sammenhængende revolutionsteori, fordrejer snarere betragtningen af Marcuses teoretiske praksis og dennes forhold til de nye sociale bevægelser. Dette kan her ikke eftervises, end ikke i grove træk; nogle henvisninger må her blot række.

Udrustet med det kritiske værkt $\varnothing j$ fra »opklaringens dialektik« og placeret $\mathrm{i}$ et efterkrigssamfund, hvis produktivitet ikke lader noget alternativ opstå i forhold til den industrimentelle fornufts herredømme, får Kritisk Teori status af en flaskepost. I hvert tilfælde tilføjer Marcuse kritikken af den »totalitære epoke« de negatoriske elementer (allerede i »Eros og civilisationen «, 1955), som henviser til de kommende årtiers protestmotiver. I sin Freud-tolkning har han opridset grundtræk af et modbillede, som tydeligt bærer $\varnothing$ kologiske og feministiske træk. De kræfter, som 
trænger på for dette alternativ, lokaliserer han for det første i subjektet, mere præcist i den menneskelige driftsstruktur, hvis samfundsmæssige modellering må blive stadig mere prekær og som også kunne afgive en driftsbasis for et frigjort samfund. (Jürgen Habermas har for nylig henvist til dette aspekt, se »Psychischer Thermidor und die Wiedergeburt der rebellischen Subjektivität« i: Habermas 1981a). Uafhængig af hvordan man idag måtte stille sig til opfattelser, som er støttet på en biologisk funderet driftsteori, - og debatten herom er på ingen måde afsluttet (jvf. Görlich m.fl. 1980) -, så er individ og subjektivitet blevet til vedvarende temaer i diskussionerne med og om de nye protestgrupper (således ikke mindst i den narcissisme-diskussion, som føres heftigt i BRD og i USA), og dette trods alle skrækvisioner om totalt samfundsmæssiggjorte individer. For det andet så Marcuse udfoldelsen af rebellerende kræfter som bundet til frisættelsestendenser indenfor det samfundsmæssige arbejdes område (arbejdsetikkens sammenbrud, arbejdsløshed, automatisering), hvis eksplosionskræfter vi idag kan se tydeligere.

Marcuse har således udstyret den kritiske flaskepost med opmuntrende »utopier«. I modsætning til andre repræsentanter fra den Kritiske Teoris mere snævre kreds, for hvem Marcuses »positive « træk forblev fremmede, hilste han opbruddet velkommen og videreudviklede sine samfundsteoretiske ansatser midt $\mathrm{i}$ håndgemænget. Hans resultater i diskussionerne med de nye protestpotentialer ser nogenlunde således ud:

- Samfundsforandring har ikke længere nogen priviligeret social bærer og lader sig ikke opvise gennem en objektivistisk rettet revolutionsteori;

- den er bundet til en subjektivitet i udfoldelse, til dens rebelske forhold til den herskende rationalitet;

- Protestpotentialet tenderer mod en diffus desintegration, som virker smittende. Organisationsansatser og kooperation finder kun sted på lokalt eller ringe formaliseret plan.

- Dens praksis er truet både indefra og udefra (regressive tendenser repression).

En fornyet beskæftigelse med Herbert Marcuse i sammenhæng med diskussionen om de nye sociale bevægelser (og ikke som en resultatløs bagtrop til en revolutionsteoretisk marxisme, således som ikke kun Breuer affærdiger ham) kunne på forskellige niveauer være frugtbart. Allerførst gælder dette for de nye bevægelsers indhold: økologi, feminisme, æstetik og individualitet er gennem Marcuse blevet behandlet i delvis skiftende fortolkninger, som sagtens kunne give ansporinger. Marcuse giver også sigtepunkter for en mulig praksis for teorien i betydningen bevidstgørende kritik, såvel i forhold til de samfundsmæssige forhold (betoning af en 
empirisk funderet samfundsanalyse) som i forhold til de udviklende eller retarderende kræfter indenfor de oppositionelle strømninger. Men det vil selvfølgelig være urimeligt heraf at håbe på en modelformet praksis eller en sikret teori.

\section{Alain Touraine}

Alain Touraine har siden 60'erne i talrige arbejder udviklet en kritisk version af ideen om det postindustrielle eller programmerede samfund, hvori de nye sociale bevægelser tildeles en central placering. Udgangspunkt er den tese, at vi lever i en fase af samfundsmæssig overgang - mutation. Det industrielle samfund går under, og konturerne af et nyt, programmeret samfund bliver stadig tydeligere (Touraine 1972, 1973, 1976). I denne proces mister $\varnothing$ konomiske afg $\varnothing$ relser og kampe deres særegenhed. Langt snarere bliver den økonomiske vækst - og videre centrale samfundsmæssige initiativer - bestemt gennem den politiske proces og den samfundsmæssige organisation som helhed. »Alle områder af det sociale liv, opdragelsen, forbruget, informationen falder mere og mere ind under det, som man tidligere kunne kalde produktivkræfterne. « (Touraine 1972: 10). Dermed bliver tendentielt alle områder til genstand for politisk formning, askriptive og traditionelle strukturer forsvinder.

Den aktuelle overgangssituation er præget af kampene om målene og magtpositionerne i det opkommende programmerede samfund. I første omgang er teknokratiet rykket ind i herskabspositionerne som samfundsformende kraft og udfolder deres projekt: »Den teknokratiske stat tilintetgør nettet af sociale relationer og kræver livet i isoleringen, som er begrænset til konsumet og af en intimitet, som er kendetegnet ved manglen på socialrelationer.« (Touraine m.fl. 1976: 12). Samtidig opstår der med de nye sociale bevægelser en modstander, som kræver en selvstændig - ligeledes som tendens altomfattende politisk formning af alle livssammenhænge, som udarbejder egne målsætninger i hverdagslivet og som vil tage fremtiden i egne hænder. Denne tendens til selvorganisering af det sociale liv er ganske vist objektivt anlagt i det programmerede samfund, men kan kun frisættes gennem social og politisk aktion (Hegedus 1981). Det industrielle samfund, og med det arbejderbevægelsen, er på ingen måde forsvundet, men den centrale samfundsmæssige konflikt har forskudt sig. De forskellige kimformer og ansatser, som idag er synlig i sociale konflikter og kampe, rummer i sig muligheden af en social bevægelse, som kan bestemme det postindustrielle samfunds fremtid. »Visheden om den store mutation «, det omfattende samfundsmæssige brud, er det orienteringsmærke, som viser vejen i Touraines nyere analyser 
(Touraine m.fl. 1978, 1981, 1982); dét er målestokken for bedømmelsen og berettigelsen for den »sociologiske intervention « $\mathrm{i}$ ansatserne til social bevægelse. Denne skal i grupperne af aktive forcere afdækningen af den centrale samfundsmæssige magtkonflikt med teknokratiet og muliggøre en tilsvarende praksis. Nye sociale bevægelser er for Touraine ikke kun krisesymptomer eller negatoriske grupperinger i en helt overmægtig samfundsmæssigg ørelsesproces, men skjuler i sig langt snarere muligheden af en samfundsmæssig aktør, ligesom arbejderklassen gjorde det i det industrielle samfund - blot nu med væsentligt mere vidtgående udfoldelsesmuligheder (nemlig historitetens). Imidlertid har vi nu (analogt til arbejderbevægelsens konstitution) ligeledes at gøre med en kulturel, social og politisk konstitutionsproces for en sådan bevægelse, hvis videreudvikling er uvis (Melucci 1980, Evers 1981, Evers/Szankay 1981).

Touraines billede af et programmeret samfund opviser ved første $\varnothing j e k a s t$ store lighedspunkter med Marcuses »éndimensionale samfund «. Den grundlæggende analytiske opfattelse bærer imidlertid en helt anden håndskrift, hvor også den er blevet videreudviklet i en stadig diskussion med bevægelserne siden Pariser-Maj-begivenhederne. Hans analytiske ansats, som blev udkastet $\mathrm{i}$ industrisociologiske studier i 50'erne og 60'erne, er handlingsteoretisk præget, også når han optager centrale motiver fra den Marxske teori (arbejds- og produktionsbegrebet står i centrum for en samfundsanalyse, som desuden er orienteret mod en radikal samfundsforandring i betydningen »udtræden af forhistorien «). Touraine vender sig polemisk mod samfundsmodeller som den i det »éndimensionale samfund « - hvori samfundet fremstår som en blok, fanget i vækstvanen og dømt til ubevægelighed gennem ideologiske apparater (Touraine 1978: 9ff). Hans konstruktion af samfundet som handlingssystem afgrænser sig bevidst fra dem, som kun levner ringe plads til handlingerne og de sociale bevægelser. Med det industrielle og endnu mere med det opkommende programmerede samfund er muligheden givet for den bevidste formning af samfundet, dets selvprogrammering. Selv om statslige og nye former for social kontrol i øjeblikket behersker billedet af samfundet, og selv om sociale bevægelser mest står som marginale kræfter ved udkanten, så er det sociologernes opgave at hæve mulighederne for selvorganisering til bevidsthed og gøre dem til konceptionelt udgangspunkt: I samfundets hjerte brænder de sociale bevægelsers ild. Også når de centrale temaer i de aktuelle sociale konflikter synes at være kulturel vægring, natur eller stat, så drejer det sig i virkeligheden - således Touraine med relation til Marx - i de sociale kampe om samfundets selvreproduktion. Modstan- 
der af de sociale bevægelser er teknokratiet som organisator af det samfundsmæssige liv. I stedet for kampen mellem kapital og arbejde i fabrikken træder modstanden fra grupper mod apparatets herredømme, som strækker sig ud over alle samfundsmæssige delområder. I disse sociale og politiske kampe drejer det sig ikke længere kun om arbejderrettigheder, profession, status eller fællesskaber, men de angår mere og mere alle samfundsmæssige områder (sundhed, sexualitet, energiproduktion etc.). Touraine udvikler en fasemodel for udviklingen af de nye sociale bevægelser:

1. Arbejderbevægelsens nedgang (dens institutionalisering som vigtig politisk kraft).

2. Kulturkritik (hensygnen i den industrielle kultur, som fremtræder som civilisationskrise).

3. Den store vægring (diffuse fremtidsforhåbninger, protestgruppernes selvindesluttethed).

4. Statskritik (kritik af repressionen og det ambivalente råb efter mindre stat).

5. Tilbagetrækning i kommunitære utopier (autonomiønsker og identitetssøgning i smågrupper og projekter).

6. Populisme (forsvar af den kollektive identitet).

7. Nye sociale bevægelser (antiteknokratiske kampe).

Også i denne udviklingsopfattelse bliver de handlingsteoretiske præmisser synlige. Dannelsesprocessen for de nye sociale bevægelser bliver opfattet som konstituering af et kollektiv-subjekt i dimensionerne »identitet « (selvkonstitution som kollektiv aktør), »totalitet « (bestemmelse af det samfundsmæssige felt og målene for kampen) og »opposition « (identificering af modstanderen). Sociale kampe - i betydningen nye sociale bevægelser - optræder først, når modstanderen er bestemt. Alle andre modstandselementer (individualitet, natur, tradition) lader sig let assimilere af den herskende elite. I de antiteknokratiske kampe drejer det sig om selvforvaltning; de lever af at bringe professionelle og ramte sammen mod apparaterne (Touraine 1978: 34ff).

Men dette er endnu fremtidsmusik. I 1978 har Touraine sammen med sine medarbejdere startet en unders $\emptyset$ gelse af forskellige sociale bevægelser i Frankrig, uden overmåde optimisme mht. deres udviklingsgrad: »Den aktuelle, næsten fuldstændige spaltning mellem på den ene side partipolitikken og på den anden side sociale bevægelser og offentlige diskussioner melder ikke om deres snarlige triumf, men betyder først begyndelsen til en rekonstruktion af det politiske liv. Nye sociale bevægelser vil først vinde betydning, når de trænger ind $\mathrm{i}$ den officielle politiske sfære, når de når fra de rolige sidegrene til hovedstrømmen.« (Touraine 1978:37). 
Den perspektivændring, som bliver mulig med Touraines analytiske definition af social bevægelse - »Den er den organiserede kollektive aktion, hvorigennem en klasse kæmper for den samfundsmæssige kontrol over historiciteten i en given, historisk bestemt sammenhæng «, Touraine 1978: 49) -, lader sig tydeliggøre gennem hans »tilbageblik « på arbejderbevægelsen: »Arbejderklassen er i det industrielle samfund ikke nogen form af varen; den er en historisk aktør, en levende, kæmpende, tænkende aktør, magtløs eller rebellerende, men altid en aktør. Vores industrialiseringshistorie og vores industrielle samfunds fungeren bliver ikke kontrolleret af mekanismer og love, men af sociale relationer og derfor af aktioner, af konfligerende sociale bevægelser, f.eks. af bourgeoisi og arbejderklasse. Resten er metafysik « (Touraine 1978: 49). Touraines opfattelse bliver således til kontrastprogrammet i forhold til den marxistiske tradition. Sociale bevægelser konstituerer sig i sociale konflikter og relaterer sig til kulturelle orienteringer - de er ikke manifestationer af objektive modsigelser. Sociale bevægelser retter sig ikke i første linie mod staten og er ikke kampe om magten. Det er klasseaktioner, som retter sig mod en social modstander. Sluttelig er sociale bevægelser ikke frembringere af mere fremskredne samfund - de kæmper indenfor et kulturelt felt for et andet samfund. Det drejer sig ikke om overvindelse. »Sociale bevægelser er ikke produkter af samfundsmæssige kriser og politisk herredømme; de kæmper om gentilegnelsen af viden, merprodukt og kulturelle modeller, som den herskende klasse har tilegnet sig til sin fordel « (Touraine 1978: 106).

Sociologernes rolle er så at bringe de positive muligheder - det højeste niveau af historisk praksis - til orde i bevægelserne, at styrke deres (selv-) forståelse og argumentere mod deres forbliven på forstadierne (1-6). Sociologen skal gøre de centrale konflikter i det nye samfund synlige. Denne dobbeltrolle af forsker og profet kendetegner den »sociologiske interventions « forskningsdesign. Nu foreligger resultaterne fra undersøgelserne af studenterbevægelsen i 1976, af økologibevægelsen og af de etniske selvstændighedsbevægelser (den occitane bevægelse) - et væld af materiale om refleksionsprocesserne i aktivgrupper, deres udvikling og perspektiver. Selvom de repræsenterer det mest fremskredne forskningsniveau, er resultaterne ejendommeligt utilfredsstillende. Usikker er vurderingen af, om de sociale konflikter har gjort skridt i retning af en social bevægelse - en usikkerhed, som har forstærket sig siden oprettelsen af venstreregeringen i Frankrig og de sociale bevægelsers aftagen. Uklart er også om ikke definitioner og undersøgelsesplan til dels har ført til videnskabshokuspokus, dvs. om ikke de sociologiske udråbere er blevet overbevist af ekkoet fra deres egne stemmer (Amiot 1980). Men trods dette 
finder jeg en intensiv beskæftigelse med studierne for nyttig, og det ville også være $\emptyset$ nskeligt, hvis der her i landet - med ulig mere udviklede nye sociale bevægelser - blev udviklet studier, som orienterede sig mod Touraines »sociologiske intervention «. Dette uden nødvendigvis at overtage dennes handlingsteoretiske præmisser eller lade sig rive med at de store armsving, som udgår fra visheden om »mutationen «.

\section{Hirsch, Roth, Altvater m.fl.}

Mere skeptisk overfor sådanne epokale forventninger forekommer de overvejelser, som ud fra Grenoble-skolens imperialismediskussion (arbejder af Palloix, Aglietta og andre - en oversigt findes hos Deubner m.fl. 1979, Bühler 1981) har formuleret en anden fasemodel for den kapitalistiske udvikling. Der gås her ud fra en aktuel krise for »Fordismen« som den dominerende samfundsmæssiggørelsesform, der har sat sig igennem i 20'erne i USA og efter den 2. verdenskrig i BRD og de højtudviklede vesteuropæsike lande.

Begrebet fordisme - som historisk henviser til Fords banebrydende Model T og teoretisk knytter an til Gramsci - står for taylorisering af arbejdet, kapitalforøgelse gennem masseproduktion af konsumgoder og gennemkapitalisering af reproduktionsområdet (Hirsch 1980, Hirsch/ Roth 1980). Den fordistisk bestemte gennemkapitalisering af samfundet (sml. også begrebet om den sig gennemsættende kapitalisme hos Funke 1978) fører til samfundsmæssige desintegrationsprocesser og medfører også som tendens en transformation af staten. Den bliver til velfærds- og overvågningsstaten, som er tilstede $i$ alle samfundsmæssige sfærer, til den integrale »sikkerhedsstat«. Denne fordistiske struktur giver også billedet af de sociale modsætninger og klassekampe nye konturer. Spaltningen og udgrænsningen, ødelæggelsen af naturgrundlaget, den fremtvungne mobilitet, opløsningen af sociale sammenhænge, de vareformede behov og relationer, undergravelsen af værdimønstre og fjernelsen af historisk bevidsthed - alt dette danner grundlaget for den tilsyneladende optrævling af de sociale konflikter, for decentraliseringen og segmenteringen af sociale bevægelser.

Forventningerne til de negatoriske potenser af katalysatorvirkende grupper bliver tydeligt nedsat i denne teoretiske sammenhæng, da et spaltet og segmenteret samfund kun giver meget ringe resonansbund for disse. Også epokale strømninger er vanskelige at forestille sig, thi de fragmenterende grøfter og politikker virker imod dem. En fælles retning for bevægelsespartiklerne er i hvert tilfælde ikke til at se teoretisk. Mere tydelig er imidlertid den mulighed, at de nye sociale bevægelser også kan være bærere af post- eller neofordistiske samfundsmæssiggørelsesformer - 
som en ny form for kapitalistisk regulering (indeholdende skyggeøkonomi, uformelle sektorer, bløde teknologier m.v.), hvis fulde omrids dog endnu ikke er tydelige.

Fordisme-opfattelsen knytter an til marxismens $\varnothing$ konomikritiske tradition og fors $\varnothing$ ger at nyvurdere reproduktionsområdet og statens rolle under de funktionsbetingelser, som sættes af en bestemt fase af den kapitalistiske samfundsmæssiggørelse. Den vender sig mod det kulturkritisk stimulerede billede af senkapitalismen og det éndimensionale samfund og forsøger at undgå den fantasiløshed, som ligger i at tale om det »tiltagende « og det »tendentielle « $\mathrm{i}$ bestemmelsen af mulige udviklinger. Men en indgående analyse af den nuværende fordisme-krise og af konturerne til den kommende »neofordistiske« samfundsmæssigg ørelsesmodus mangler fortsat. En sådan kunne knytte an til den nuværende diskussion om de »lange bølger« (Altvater 1982, Huber 1982), hvis den undlod at give for megen plads for den teknologiske opfattelse omkring basisinnovationer og fastholdt, at en ny fase i akkumulationsprocessen kun kan bæres af en omfattende socioøkonomisk og politisk nystrukturering af samfundsmæssige institutioner. For analysen af de nye sociale bevægelser giver dette den konsekvens, at de begribes som konfliktformer i en specifik samfundsmæssiggørelsesmodus og dennes krise - muligvis også som modstandsformer til eller varsler om en neofordisme. Der er således ikke grund til at ringeagte de nye sociale bevægelser, som er fuldt på højde med tiden, og som ikke lader sig presse ind i arbejderbevægelsens normative mønstre. Men de er ikke nødvendigvis den antagonistiske modspiller til et teknokrati. Tværtimod er de muligvis integrerede bestanddele af det fremtidige akkumulationsprojekt - og dette ikke som kollektivsubjekt, men i deres myriadeartede form.

Fortrinnene ved denne »fordisme«-opfattelse, som endnu kun foreligger i grove træk, ligger for mig at se i det forhold, at den sætter fingeren centralt på et svagt punkt i diskussionen omkring de nye sociale bevægelser. Denne diskussion er kørt fast i alternativet kontinuitet ( $\varnothing$ kologisk oplyst kapitalisme etc.) eller brud ( $\varnothing$ kosocialisme eller tilsvarende katastrofebilleder). Med »fordisme«-opfattelsen er der her tale om en berigelse i form af den historisk oplyste variant: drastisk forandrede reproduktionsmodeller på grundlag af kapitalvaloriseringens kontinuitet.

\section{Jürgen Habermas}

Jürgen Habermas har for nylig grundlagt en teori om den kommunikative handlen (Habermas 1981). Deri præciserer han tidligere ansatser til en tolkning af de nye sociale bevægelser (Habermas 1977, 1979). Disse er centreret omkring tesen om »kolonialiseringen af livsverdenen gennem et 
selvstændiggjort $\varnothing$ konomisk og administrativt system « - en tese, som er udviklet i tilknytning til Max Webers teori om den samfundsmæssige rationalisering (Habermas 1979: 19). Gennem livsverdenens erosionsprocesser kommer det til en overlejring af gamle konflikter med nye konflikter (produktivistisk kærne versus vækstkritisk periferi), i hvilke den »kommunikative hverdagspraksis' egenbetydning « og »livsformernes grammatik « forsvares. I forhold til »lidelsen under afsavnsfremtrædelserne i en kulturelt forarmet og énsidigt rationaliseret hverdagspraksis « reagerer de nye sociale bevægelser »gennem en revitalisering af forspildte udtryksog kommunikationsmuligheder« (Habermas 1981, bd. 2: 580f).

Ud fra perspektiverne i Habermas' »teori om det moderne«, som konstaterer en ambivalent situation af historisk mulighed for og samtidig synlig trussel mod kommunikativ handlen, fremstår de nye konflikter og bevægelser væsentligt som tilbagetræknings- eller modstandspotentiale, som sigter mod en inddæmning af den fremadskridende formal-organisering af handlingsområder. Nye territorier kan de - ifølge Habermas, som dog tilskriver kvindebevægelsen emancipatoriske kvaliteter - imidlertid ikke åbne. De nye sociale bevægelser er også indfanget $\mathrm{i}$ »det modernes dialektik«, og der er for dem kun bagudgangen åben.

Det er derfor også følgerigtigt, når Habermas holder fast ved begrebet om neopopulismen og undgår begrebet om de nye sociale bevægelser. Disse bevægelser er populistiske »for det første fordi der ikke er nogen klar tilordning til sociale grupper, og for det andet fordi de politiske orienteringer i det væsentlige er negativt bestemt som afværgelse mod anonyme bureaukratiske strukturer, som afværgelse af det, der subjektivt erfares som farer ved det tekniske fremskridt, som afværgelse af ikke særlig præcist analyserede farer slet og ret. Sådanne grupper holdes ikke sammen gennem et fælles politisk målperspektiv« (Habermas 1981a: 318f). Deres politiske status forbliver derfor nødvendigvis ambivalent. På den ene side udgør de nødvendige korrektiver og modvægte til de $\varnothing$ konomiske og bureaukratiske rationaliseringsstrategiers imperialisme, thi de kriser, som opstår i den materielle reproduktions områder, opfanges med en patologisering af livsverdenen som pris. Derudover kæmper kvindebevægelsen, og også de gamle og bøsserne, for virkeliggørelsen af et uindløst løfte fra det moderne: for universel lighed. Men trods dette opviser disse bevægelser - også kvindebevægelsen, hvor den går ud over lighedsfordringen - stærkt antimodernistiske træk, som stiller spørgsmålet om hele de moderne som projekt. Under de nuværende samfundsmæssige betingelser ser Habermas for de nye protestbevægelser fare for en koalition med meget forskellige konservative kræfter, som også truer de positive resul- 
tater af det moderne (politiske friheder, universalistisk moral, uddifferentierede sfærer af videnskab og kunst).

Habermas' samfundsteoretiske udkast sigter på en kombination af bevidstgørende og »frelsende« kritik. »For os marxister stiller der sig det problem, hvordan de erfaringer, som artikuleres i sådanne bevægelser, bedst kan fortolkes, således at vores udlægning kan accepteres af de umiddelbart ramte grupper, således at vores hypotese, at disse bevægelser er blevet forårsaget af den politisk ukontrollerede kapitalistiske udvikling, kan gøres troværdig.« (Habermas 1981b: 496). Til dette kommer en frelsende kritik - i tilknytning til Benjamin -, som peger mod en tilegnelse af ekspertkulturen ud fra livsverdenens synsvinkel, thi den esoteriske uddifferentiering af forskellige kulturområder (videnskab, kunst, moral) har ført til en forarmelse af livsverdenen og indkapslet perspektiverne for et godt liv. »En differentieret tilbagekobling af den moderne kultur med en hverdagspraksis, som er henvist til vital overlevering, men forarmet gennem den rene traditionalisme, vil imidlertid kun lykkes, hvis den samfundsmæssige modernisering også kan fæstnes i andre ikkekapitalistiske baner, hvis livsverdenen kan udvikle institutioner, som begrænser den systematiske egendynamik i det $\varnothing$ konomiske og administrative handlingssystem.« (Habermas 1981b: 462).

Med sit formidlingssystem af handlings- og systemteori, af et system og en livsverden, som koplet fra hinanden og samtidig relateret til hinanden, er Habermas delvist blevet mødt med skarp afvisning. Således taler Stefan Breuer om en »afpontensering af den »Kritiske Teori«: »Habermas ønsker en kapitalisme, som begrænser sig til udbytningen af arbejdet, og et kommunikativt bureaukrati, som standser op ved dørene til skole, universitet, parlament og familie. Det sene 18. århundrede har vel nogenlunde svaret til denne forestilling «. (Вreuer 1982: 140) Sådanne fortolkninger begunstiges af den omstændighed, at Habermas endnu ikke reelt har gennemført sit program for en analyse af den kapitalistiske udvikling i dimensionerne system og livsverden. Men at den teoretiske problemstilling - en formidling mellem handlings- og systemteori - ikke kan fejes af bordet med let hånd burde vel denne hastige gennemgang af de samfundsteoretiske ansatser have vist. Thi sociale bevægelser befinder sig nok i et skæringspunkt, som enten forleder til en handlingsteoretisk forflygtigelse af samfundsmæssige strukturer eller til fastlåsning af de bevægede protester i strukturkategorier.

Jeg vil på dette sted undlade en »teorisammenligning « og heller ikke foreslå nogen kombination af forskellige teorielementer. Muligvis er diskussionen også endnu for uudviklet til sådanne fors $\emptyset$ g. For de videre debatter finder jeg følgende konklusioner vigtige: 
1. Diskussionen med nye sociale bevægelser nødvendiggør samfundsteoretisk refleksion. Hvor deres substans ikke blotlægges, er der fare for det, som et gammelt ordsprog så rammende har karakteriseret: »Som man råber i skoven får man svar«.

2. Det er øjensynligt ikke tilstrækkeligt at foretage nutidsanalyser. De nye sociale bevægelsers aktionsfelt henviser til mulige fremtider, som de socialvidenskabelige forskere ikke kan undslå sig for at medtematisere. Minervas ugle må flyve allerede før skumringen.

3. Når nye sociale bevægelser sigter mod samfundsmæssige udviklingsveje, så er diskussionen i forhold til grupper, aktioner, projekter og konflikter i bevægelsen selv en vigtig mulighed for at videreudvikle samfundsanalyserne.

4. Berøringsangsten i forhold til »revolutionsteoretiske« spørgsmål bør forsvinde. I dette drejer det sig ikke om at operere med visheder, men om bevægelsers mulige bidrag i sammenhæng med samfundsmæssig forandring.

5. De nye sociale bevægelser tvinger de socialvidenskabelige forskere til en fornyet refleksion over deres praksis. Dette gælder for såvel deres forskningspraksis som for deres politiske engagement. Modellerne fra de partiintellektuelle i arbejderbevægelsens tradition eller fra de venstreintellektuelle i studenternes protestbevægelse udgør ikke længere brugbare orienteringer. Hengivelse til indsigt er der vel heller ingen af de præsenterede ansatser, der vil begrænse sig til. Det, der er brug for, er nye kooperationsformer (og en tilsvarende teoretisk »overbygning «), hvori den sociologiske refleksion kan være produktiv.

\section{Litteraturliste}

Altvater, E., 1982: Der Kapitalismus vor einem Aufschwung? Über Theorien der 'langen Wellen' und der 'Stadien', i: Wirtschaft und Gesellschaft 2/82, $195 \mathrm{ff}$.

Amiot, M., 1980: L'intervention sociologique, la science et la prophétie, i: Sociologie du Travail 4/80, $417 \mathrm{ff}$.

Babrom R., 1980: Elemente einer neuen Politik, Berlin

Berger, P.L. u.a., 1975: Das Unbehagen in der Modernität, Frankfurt/New York

Brand, K.W., 1982: Neue soziale Bewegungen - Eine Zwischenbilanz, Opladen

Breuer, S., 1977: Die Krise der Revolutionstheorie, Frankfurt/M.

Breuer, S., 1978: Subjektivität und Maschinisierung, i: Leviathan 1, $87 \mathrm{ff}$.

Breuer, S., 1982: Die Depotenzierung der Kritischen Theorie, i: Leviathan 1, 132 ff.

Bühler, M., 1981: Weltmarkt, internationale Arbeitsteilung und nationale Reproduktion, i: PROKLA 44, $139 \mathrm{ff}$.

Deubner, C., u.a., 1979: Die Internationalisierung des Kapitals, Frankfurt/New York

Ellul, J., 1974: Von der Revolution zur Revolte, Hamburg

Evers, A., 1980: Die politische Bedeutung der sozialen Bewegungen,: arch 49, $36 \mathrm{ff}$.

Evers, A., 1981: Was entsteht mit den 'neuen sozialen Bewegungen'?, Man., Aachen

Evers, A., u. Z. Szankay, 1981: Das gerissene Band, i: PROKLA 43, 43 ff. 
Funke, R., 1978: Sich durchsetzender Kapitalismus, i: Starnberger Studien 2, Frankfurt/M., 219 ff. Görlich, B. u.a., 1980: Der Stachel Freud, Frankfurt/M.

Glotz, P., 1982: Die Beweglichkeit des Tankers, München

Gorz, A., 1980: Abschied vom Proletariat, Frankfurt/M. (da., Farvel til Proletariatet, 1981).

Gorz, A., 1980a: Ökologie und Freiheit, Reinbek. (da., Økologi og frihed, 1980).

Guggenberger, B., 1980: Bürgerinitiativen in der Parteiedemokratie, Stuttgart u.a.

Habermas, J., 1977: Stumpf gewordene Waffe aus dem Arsenal der Gegenaufklärung, i: Duve, F. u.a., (Hrsg.), Briefe zur Verteidigung der Republik, Reinbek, 54 ff.

Habermas, J., 1979: Einleitung, i: Habermas, J., (Hrsg.), Stichworte zur, Geistigen Situation der Zeit', Band 1, Frankfurt/M., 7 ff.

Habermas, J., 1981: Theorie des kommunikativen Handelns, Frankfurt/M.

Habermas, J., 1981a: Philosophisch-politische Profile, Frankfurt/M.

Habermas, J., 1981b: Kleine politische Schriften I-IV, Frankfurt/M.

Hegedus, Z., 1981: The political ecology movement and the new protest actor, Man., Paris

Hirsch, J., 1980: Der Sicherheitsstaat, Frankfurt/M.

Hirsch, J. u. R. Roth, 1980: 'Modell Deutschland' und neue soziale Bewegungen, i: PROKLA $40,14 \mathrm{ff}$.

Huber, J., 1982: Die verlorene unschuld der Ökologie, Frankfurt/M.

Inglehart, R., 1981: Post-materialism in an environment of insecurity, i: APSR, $880 \mathrm{ff}$.

Katz, B., 1982: Herbert Marcuse and the art of liberation, London

Kitsuse, J.I., 1980: Coming out all over: deviants and the politics of social problems, Social Problems 1, $1 \mathrm{ff}$.

Kraushaar, W., (Hrsg.), 1978: Autonomie oder Getto?, Frankfurt/M.

Kriesi, H., 1982: Soziologische Methodologie und die Rebellion der Betroffenen i: KZfSS 4, $748 \mathrm{ff}$.

Löw-Beer, P., 1981: Industrie und Glück, Berlin

Marcuse, H., 1967: Der eindimensionale Mensch, Neuwied/Berlin

Marcuse, H., 1978: Über Bahro, den Protosozialismus und den Spåtkapitalismus, i: Kritik 19, 5 ff.

Marcuse, H., 1980: Das Ende der Utopie, Frankfurt/M.

Mast, C., 1980: Aufbruch ins Paradies? Die Alternativbewegung und ihre Fragen an die Gesellschaft, Zürich

Mayer-Tasch, P.C., 1981: Die Bürgerinitiativbewegung, Reinbek, überarb. Aufl.

Mayer-Tasch, P.C., 1980: Ökologie und Grundgesetz, Frankfurt/M.

Melucci, A., 1980: The new social movements: a theoretical apporach, i: Social Science Information 2, $199 \mathrm{ff}$.

Narr, W.D., 1980: Zum Politikum der Form, i: Leviathan 2, 143 ff.

Peters, J., (Hrsg.), 1980: Nationaler 'Sozialismus' von rechts, Berlin

Pohrt, W., 1980: Ausverkauf - Von der Endlösung zu ihrer Alternative, Berlin

Schimank, U., 1981: Neoromantischer Protest im Spätkapitalismus, Diss., Bielefeld

Thompson, E.P., 1963: The making of the English working elass, London

Thompson, E.P., 1980: Plebeische Kultur und moralische Ökonomie, Frankfurt/M. u.a.

Touraine, A., 1972: Die postindustrielle Gesellschaft, Frankfurt/M.

Touraine, A., 1973: Production de la société, Paris

Touraine, A., 1976: Briefe an eine Studentin, München

Touraine, A., 1976: Jenseits der Krise, Frankfurt/M.

Touraine, A., 1978: La voix et le regard, Paris

Touraine, A., u.a., 1978a: Lutte étudiante, Paris

Touraine, A., 1980: L'Aprés-socialisme, Paris

Touraine, A., u.a., 1981: Le pays contre l'état, Paris

Touraine, A., u.a., 1982: Die antinukleare Prophetie, Frankfurt/New York

Vester, M., 1970: Die Entstehung des Proletariats als Lernprozess, Frankfurt/M. (da. Proletariatets opståen som læreproces, 1978).

Vester, M., 1983: Proletariat und neue soziale Bewegungen, i: Grottian, P./W. Nelles (Hrsg.), Grossstadt und neue soziale Bewegungen, Basel, 1 ff. (da. overs. i Kurasje 34). 